\title{
Correction to: Conventional and transgenic strategies to enhance the acid soil tolerance of barley
}

\author{
Jéssica Rosset Ferreira - Euclydes Minella • \\ Carla Andréa Delatorre • Emmanuel Delhaize • \\ Peter R. Ryan • Jorge Fernando Pereira
}

Published online: 13 February 2018

(C) Springer Science+Business Media B.V., part of Springer Nature 2018

\section{Correction to: Molecular Breeding (2018) 38:12} https://doi.org/10.1007/s11032-017-0769-7

The original version of this article unfortunately contained a mistake. The online supplementary material (composed of Table S1, Fig. S1, and Fig. S2) was omitted in the published online version. The supplementary material is available in this version.

The online version of the original article can be found at https://doi.org/10.1007/s11032-017-0769-7

Electronic supplementary material The online version of this article (https://doi.org/10.1007/s11032-018-0786-1) contains supplementary material, which is available to authorized users.

J. R. Ferreira - C. A. Delatorre

Federal University of Rio Grande do Sul, PO Box 15096, Porto

Alegre, RS 91501-970, Brazil

E. Minella $\cdot$ J. F. Pereira $(\bowtie)$

Embrapa Trigo, Rodovia BR 285 km 294, Passo Fundo, RS

99001-970, Brazil

e-mail: jorge.pereira@embrapa.br

E. Delhaize · P. R. Ryan

CSIRO Agriculture and Food, GPO Box 1700, Canberra, ACT

2601, Australia

Present Address:

J. F. Pereira

Embrapa Gado de Leite, Rua Eugênio do Nascimento 610,

Juiz de Fora, MG 36038-330, Brazil 